\title{
Dadabayeva G.R.
}

Doctor of Historical Sciences, Associate Professor, KIMEP University,

Kazakhstan, Almaty, e-mail: dgulnara@kimep.kz

\section{RUSSIAN TURKESTAN IN 1870S: USA DIPLOMAT NOTES}

The rapid conquest of Central Asia realized by the Russian empire during 1860s is still a case to raise and discuss some acute questions. As A. Morrison (Morrison 2014) rightly noted the main explanations are divided between «Great Game» security concept (Carrere d'Encausse, Pierce, Bennigsen 1969; Morrison 2008) and "Cotton Canard» approach mainly represented in works of Soviet historians (Khalfin 1960; Khalfin 1965; Kastel'skya 1980). However, historians pay little attention towards the reaction of the other countries concerning Russian presence in Central Asia. The aim of the paper was using archival documents from Britain's Foreign Office (Ministry of Foreign Affairs of Great Britain) to enlarge the scope of the Russian colonization in 1870s. This article is based on the report of Mr. Eugene Schyler, Secretary of the United States Legation in St. Petersburg after his trip to Russian Turkestan made in 1874. He exposed some weak points in administrative system while as he insisted the Russians «counterpoised» British moves in the region. lomat.

Key words: Russian Turkestan, colonization, administrative system, "Great Game», American dip-

\author{
Аадабаева Г.Р. \\ т.ғ.А., Аоцент, КИМЭП Университеті, \\ Қазақстан, Алматы қ., e-mail: dgulnara@kimep.kz \\ 1870 жылдардағы Ресей Түркістаны: \\ америка дипломатының жазбалары
}

1860 жылдары Ресей империясының Орталық Азияны қарқынды жаулап алуы тарихи оқиға екені белгілі, бірақ ол әлі күнге дейін жауабын беруге қиыншылықтар туындатады. Ағылшын тарихшысы А. Моррисон (Morrison 2014) атап өткендей, бұл оқиғаның негізгі түсініктемелері екі бағытпен: «Үлкен ойын» оның қауіпсіздік концепциясымен (Carrere d' Encausse, Pierce, Bennigsen 1969; Morrison 2008) және «Мақта мифі», негізінен Кеңес тарихшыларының еңбектерінде сараланған (Ха^фин 1960; Халфин 1965; Kastel'skya 1980). Аегенмен, тарихшылар Ресейдің Орталық Азияны басып алуға қатысты үшінші елдердің наразылығына назар аудармаған. Бұл мақаланың мақсаты Britain’s Foreign Office (Ұлыбританияның Сыртқы істер министрлігі) құжаттарын пайдалану арқылы 1870 жылдардағы ресейлік отарлау саясаты туралы түсінігімізді кеңейту. Мақала Санкт-Петербургтегі америкалық, дипломатия миссиясының хатшысы Юджин Шайлердің баяндамасы негізінде, 1874 жылы Ресей Түркістанына барған сапарынан кейін жазылған. О^ Ресей әкімшілігінің әлсіз жерлерін аша отырып, сол кезеңде Ресей ағылшындардың қатысуын азайтып, өңірдегі жағдайды «теңестірді».

Түйін сөздер: Ресей Түркістаны, отарлау, әкімшілік жүйе, «Үлкен Ойын», америкалық, Аипломат.

Аадабаева Г.Р.

А.и.н., Аоцент. Университет КИМЭП,

Казахстан, г. Алматы, е-mail: dgulnara@kimep.kz

Русский Туркестан в 1870-е годы:

записки американского дипломата

Стремительное завоевание Центральной Азии Российской империей в 1860-е годы является историческим событием, которое до сих пор вызывает вопросы, на которые непросто ответить. Как заметил английский историк А. Моррисон (Morrison 2014), основные объяснения этого события тяготеют к Авум полюсам: «Большой Игре» с ее концепцией безопасности (Carrere d'Encausse, Pierce, Bennigsen 1969; Morrison 2008) и «Х^опковым мифам», который представлен 
в основном работами советских историков (Халфин 1960; Халфин 1965; Kastel'skya 1980). Тем не менее, историки почти не уделяли внимания реакции третьих стран по поводу российского присутствия в Центральной Азии. Целью данной статьи является использование документов из Britain's Foreign Office (Министерство иностранных дел Великобритании), чтобы расширить наше представление о российской колонизации 1870-х годов. Статья написана на основе доклада ЮАжина Шайлера, секретаря американской дипломатической миссии в Санкт-Петербурге, который был написан им после поездки в Русский Туркестан в 1874 году. Он вскрывает слабые места российской администрации и в то время же указывает, что Россия "сбалансирова^а» ситуацию в регионе, уменьшив английское присутствие.

Кмючевые слова: Русский Туркестан, колонизация, административная система, «Большая Игра», Американский дипломат.

\section{Introduction}

Russian conquest of Turkestan region western historians traditionally refer to security driven act as part of Great Game to save from the British their share of Central Asian region (Carrere d'Encausse, Pierce, Bennigsen 1969; Morrison 2008). However, in spite of the "Cotton Canard» move inspired as soviet historians suggested by economic interests of the Russian business (Khalfin 1960; Khalfin 1965; Khalfin 1974; Kastel'skya 1980) only Alexander Morrison made an attempt to compare colonial regimes in Russian Turkestan and British India (Morrison 2014). Judging the benefits of conquest it should be stated that Russia finally found a way to establish control over Middle Asian khanates, to have regular trading relations with Eastern Turkestan and protect its southern borders from the potential expansion of Chinese empire and Great Britain (Tarasov 2013). Two Anglo-Afghan wars, 1838-42 and 1878-80 ended with the establishment of English dominance over Afghanistan. Later this territory became a main center of anti-Russian activity. In answer Russian empire launched a series of the military campaigns against Middle Asian khanates. This security moves became the ground for postsoviet works of local historians focusing primarily on colonial and post-colonial aspects of the Russian presence in Central Asia (Abdurakhimova 2002; Khalid 2007). However, international dimension of Central Asian colonization didn't receive much attention of historians. Mostly British and Russian historians were interested in reflecting over consequences of Russian presence in Central Asia so Schyler's notes on his trip to Turkestan added some new details to analyze Turkestan situation. In present article was used information from Schyler's report to American embassy after his journey. Thus the present paper is partly an attempt to show the reaction of third countries such as USA that was keeping friendly relations with Russian empire in this period.

\section{Russian conquest and administration}

The campaign of 1864 , which resulted in the capture of Turkestan Aulie-Ata and Chimkent, was a result of a plan to unite the outlying posts of fort Peroffsky and Verniy. Thus, Russian government was to embrace the whole Kyrgyz steppe which at this time was intended to place under the charge of special administrator, general Ignatiev. The capture of Tashkent in 1864 by colonel, then general Chernaiev was realized without order of St. Petersburg. Still, its union with the empire was agreed and Russia obtained a foothold in the Central Asian region. The whole new acquired territory was placed under the charge of the Governor General of Orenburg, and general Romanovskyi was appointed governor in the place of general Chernaiev.

A commission was appointed to draw up special regulations for the government of the new province, in accordance with the local necessities. Before this commission had finished its work and Russian boundaries were enlarged by the conquest of Khojent. Consequently, the new province was administrated by special Governor General, independent of Siberia or Orenburg with extraordinary power.

General von Kauffman, who had just been removed from Vilno, was appointed to this post and the province of Semirechier with its capital Verniy was detached from Western Siberia and added to new province of Turkestan. General Kauffman arrived to Tashkent in 1864 and on his report, the new regulations, which had not, up to this time, approved by Emperor, were permitted to be put on trial until the end of 1870. The district of Zaravshan which, after the conquest of Samarkand in 1868, remained in Russia was included into this project.

A new project was drawn up in 1871 but returned for some adjustment and when it finally reached St. Petersburg in 1872, did not receive an emperor's consent. Another project that was brought to St. Petersburg by the governor general also was rejected 
by Council of the empire. Thus, since the beginning of 1871 the province of Turkestan has been in an irregular position (Dempsey 2010).

The basis of both project were the combination of civil and military power in the same hands, and the internal administration of the native population over all matters not having a political character by representatives elected by them in accordance with their customs. The main characteristics of the project were following.

The governor-general, who was at the same time a commander-in-chief of the forces, had the same position as governor general in other parts of the empire and, besides, in case of need, to suspend the regulations or to make exceptions to them. He had also a full power for carrying on diplomatic negotiations with the neighboring countries. The two governors of the provinces of Semirechier and Syr-Daria were under him respectively, and the commanders of Zaravshan district were not included into regulations. The provinces were further divided into five districts in Semirechier and eight in SyrDaria, as well as city of Tashkent which constituted a separate administrative district. At the head of these districts (uezds) were prefects or commandants who had police and general supervision of all the inhabitants of the district, Russians as well as natives. Originally resembling the district officials in Russia, these prefects had come to occupy a more powerful and independent position. The nomad population (Kyrgyz) was divided into «volosts» (communities) and «auls» (camps). The auls comprised from officers, and should be disposed to uphold them in spite of all charges of maladministration. Although the most glaring acts of maladministration had been committed by the district prefects or commanders, the general tone set by the governor general is such as to naturally led to this result, and to render it almost hopeless to expect anything better.

\section{Was Russian administration irresponsible?}

The prefects being removed, to a certain extent, from the observation and control and falling soon into the ways and methods of former Central Asian government abused their powers and considered themselves as almost irresponsible. A striking example of this way was the management of Karakaminski district, one of the most fertile and thickly settled in the whole province. This district surrounded but not included the city of Tashkent. The prefect of this district in one year levied 90,000 roubles of illegal taxes, all of which he spent. Besides, he resided five miles of the house of governor general and was known living in a style, with frequent dinners and gambling parties entirely impossible on his salary 2,400 roubles a year. Among other things, saving fund was instituted for the benefits of population. However, it had been allowed by a subsequent regulation approved by governor general to spend this money for the administrative needs of the district. This money, 22,000 roubles entirely disappeared and no accounts of its expenditure were found except it was said that it had been used in fitting up the house of prefect. Money was taken from the natives at all times and under all pretenses, and a grossly illegal order was issued that forbidden to all natives to cross Syr-Daria river and other places specified in the order. All the persons blamed to break the order were threatened to send to Siberia. The pints specified were places belonging to friends of prefect.

When the last matter became too scandalous, the governor general felt obliged to take some notice and he removed prefect from this district. However, instead of his punishing he appointed him to another locality, stating that he considered him as «most useful officer».

On the other hand, many persons who endeavored to enlighten the public as to the state of affairs were immediately punished. For instance, the commandant of the district ....was removed and sent out of the province for writing a letter to St. Petersburg for publication. The letter never was published though it contained very sensitive information about riots in Khodjend that were caused allegedly by excessive taxation which was not that Russians promised at first. They also could not be explained by vaccination measures as it had been given out. Similar cases were numerous. When the governor general received a paper showing the gilt of the employee he tore it without reading saying: »I know this person so well, and I believe him to be such an honest man, that I cannot thing that such things are possible.»

In some cases these acts that brought very important consequences were issued due to a personal desire or from the motives of intrigues. An officer named Emmonds who was in possession of the government funds gave information that he was robbed by Kyrgyz. The chief Kyrgyz living in the neighborhood of the alleged occurrence were arrested and after a long examination, several of them confessed they were guilty. Unfortunately, money was not found. While the trial was going on, Emmonds committed a suicide leaving a letter where he stated that he was not honest man and he spent the money mad made this excuse to 
clear himself. Of course, Kyrgyz were released, but the question arose- why they had confessed? After investigation it was found that judicial officer baron Grevenitz von Kerney had exported confession from them by means of torture. This practice was wholly at variance with Russian law and certainly the most disastrous for the Russian influence among Kyrgyz.

When the Russians advanced into Central Asia they found many ready to welcome them, partly because they were discontented with the law of the Kokand Khan and Emir of Bokhara. The torture and executions which were practice by them made Kyrgyz desired anything except peace. Immediately after Russian occupation there was an immense feeling of relief that now every human's life was his own and the property was secure from arbitrary taxation and seizure. Besides, the large non-productive population caused a great demand for labor, and for the necessities and luxuries of life that consequently led to a rapid growth of prices. Rich landowners and merchants could use all advantages of this situation while poorer people were not affected by this tendency for the first time. Later on, with the growth of Russian immigration prices had risen and it cost twice more as much to support working people. The merchants used advantages of speculation due to large number of contracts necessary for maintaining military forces in the region. But th4ese things must work in time thus the government had to work skillfully to avert any feelings of discontent. Circumstances were the same when English forces occupied Kabul, but things succeeded each other more quickly there and English were finally obliged to retreat.

The citizens of Central Asia were by no means the same as Afghans: they were more pacific to incline more to peace deal. They wanted to be under Moslem law to regulate all issues with taxes to forget all evils of the Khan's rule. So, the main task of the local population was to settle all existed and future problems with Russian administration peacefully. However, it would be unwise to underestimate that the local rules even the most tyrannical were always limited by Sharia law. It was the fundamental of any Moslem society here in Central Asia.

\section{Attitude to Russian law}

The troublemaking moment in regard to the Russian administration in Central Asia is attitude of the native population towards Russian law. Most of them saw no reason to follow it because they were convinced that the law is an arbitrary will of the
Russian rulers. Thus, their vision of new system of taxation and administration was not in line with the expectation of the new colonial officials. Taxation before was regulated by the rules of Sharia that was changed but not adopted yet. This discontent existed and there were various facts that proved this fact (Becker 1994).

In 1872 in Khojent was a great disturbance of the local population suppressed by regular military forces and as a result the leaders of the riot were executed. This unrest was supposed to be against for universal vaccination and was caused by the idea that men would be recruited to the army. However, the general disagreement was explained by rise of taxes. Angry mean who remembered that Russia promised to lower taxes finally discovered that taxes opposite became higher than before. The same year the attack was made on the station at Karaser, on the road between Tashkent and Khojent. One officer was killed and the station was destroyed. Though the administration was at first convinced that this act was committed by marauders, later it was turned out as political conspiracy in which many respected native people participated. The leader of the unrest was Ishan, a known fanatic and his expedition of some 20 men went out Tashkent quietly by a roundabout way and then fell upon the first station with the aim of breaking communication and exciting the country.

The government was warned of this plot several days in advance but refused to act though they could easily prevent it. Russian administration was convinced that there is nothing on foot. During the early spring 1873 most of the Kazakhs who inhabited district of Chimkent left the country preferring desert of Kzyl Kum to living under Russian rule.

Various projects had been proposed for starting factories for cotton spinning and the fabrication of silk. Sometimes the government provided material assistance to such projects but with the exception of silk spinning establishment in Khojent (belonged to Moscow Company) nothing was done.

The agriculture and trade of the country could develop at some extent Russian colonies but the Russians were permitted to buy lands outside of the cities and launch agricultural projects.

Colonel Glukhovski had an idea to establish a great fair in Tashkent, he tried to persuade the government that this fair would have a positive impact to the whole Central Asia. Consequently buildings were constructed two miles away from the city. Unfortunately, no traders came to purchase or sell goods and administration ordered to close Tashkent bazar (- local market) for the whole 
period of fair work. This order proved inefficiency of administration orders when heavy fines were imposed on those traders who didn't come. They were sent to fair under the guard of Cossacks but even this had slight effect.

The Russian merchants also were obliged to petition for a repeal of this order. They explained that if the natives were forbidden to trade they would be unable to pay for the goods demonstrated by them. The Russians found also inconvenient to keep warehouses for their goods at the fair as well as their private establishments. Thus, the fair failed while it cost for the government for three or four years nearly 400,000 roubles annually.

\section{A promised land}

Turkestan was seen in the empire after its conquest as «promised land.» What initially attracted Russian empire, Peter the Great particularly, was gold and other precious metals that could be found here in large quantities. When Tashkent was finally occupied by Russian military forces people talked about gold and other mineral wealth to start mining in the mountains and used irrigated lands. However, at this time mining process was impossible to launch due to different reasons such as high cost of the coal found near Khojent to transport to Tashkent. Agricultural sector was also questionable because the cost of keeping military forces in the region exceeded all potential benefits of the fertile land exploitation.

Trade was also problematic issue: native population was not involved into treading relations with Russia accompanied also by the fall of Middle Asian trade after the Russian conquest. Except, the population of Central Asia was not large enough to get advantages of the trading operations: they could export prints, cotton products, cloths, tea and some small articles. Decade later the main export goods from Central Asia was cotton, worse in quality in comparison with cotton imported from abroad and fine sheep skins well known as Karakul. Russian administration supposed to increase trade of dried fruits and horse-hair but unfortunately communication between Turkestan and European part of Russian empire was extremely bad to make trade difficult. There also known fact that $14 \%$ of the camels were destroyed during Kniva expedition and problems of transportation immediately increased during winter and spring of 1873. Immediately, after the campaign prices increased that worsened significantly economic situation for the local farmers.

\section{Instead of conclusion: some notes on Russian} foreign policy in Central Asia

It can be barely said that Russians had a fixed policy in Central Asia in that period. The government in St. Petersburg had been always sincerely desirous of refraining their conquest by circumstances often compelled them to act aggressively. The Russian elite consequently had been found impossible to give up conquests that were made by empire without loss of prestige.

I am convinced that there is not the slightest desire to make any attack upon India, but naturally the Russians would dislike to see England extent her influence nearer that it now does in Central Asia. (from the report of E. Schuyler, 1874: 13).

American diplomat also expressed his concerns over difficulties that arose in regard to the English policy in Kashgar (Campbell 2014). English criticism, however, and English diplomatic interference had been many effects on the Russian policy. Foreign Office felt strong objection to take any steps in Central Asia without being involved into troubles with Russian government. The latter also didn't feel strong enough to take her own course without regards to what England could say or think. Here Schuyler stressed that opposite to central imperial government the Governor General seemed to play a part of pacificator of Central Asia. The treaties that were signed with various states including Khiva khanate after successful military expedition finally put down the last element of disorder in Central Asia. (from the report of E. Schuyler, 1874: 13).

\section{Archival Sources}

Report to the United States Government by Mr. Eugene Schuyler. Britain's Foreign Office. Oriental and India Office Collections. Letters from India. L.PS.7.4. F 1-170. 


\section{References}

Abdurakhimova N. (2002) The Colonial System of Power in Turkestan . International Journal of Middle East Study. 2002, 34. Campbell I.W. (2014) Our friendly rivals: rethinking the Great Game in Ya'kub Beg's Kashgaria 1867-77 . Central Asian Survey, 2014 (33), issue 2 199-214.

Gavin Hambly with Alexander Bennigsen, Helene Carrere d'Encausse, Rischard Pierce (1969) Central Asia. Dell Publishing Co., Inc., New York, p. 2.

Dempsey, Timothy A. (2010). Russian Rule in Turkestan: A Comparison with British India Through the Lens of World Systems. Thesis, Ohio State University, 2010.

Khalfin N.A. (1974) Rossiya i khanstva Sredney Azii: (Pervaya pol. XIX v.) [Russia and the Khanates of Central Asia: (First half of the XIX century)]. M.: Nauka

Khalfin N.A. (1965) Prisoyedineniye Sredney Azii k Rossii (60-90-ye gody XIX v.) [Accession of Central Asia to Russia (6090s of the XIX century)]. Moskva: Nauka

Khalfin N.A. (1960) Politika Rossii v Sredney Azii [Russian politics in Central Asia]. Moskva: Nauka.

Khalid A. (2007) Introduction: Locating the (post-) colonial in Soviet history. Central Asian Survey (December 2007) 26(4), 465-473.

Kastel'skaya Z.D. (1980) Iz istorii Turkestanskogo kraya [From the history of Turkestan region]. Moskva: Nauka.

Morrison, Alexander (2014) Killing the Cotton Canard and getting rid of the Great Game: rewriting the Russian conquest of Central Asia, 1814-1895. Central Asian Survey, 2014 (33), issue 2 131-142.

Morrison, Alexander (2008) Russian Rule in Samarkand: A Comparison with British India, New York: Oxford University Press.

Seymour Becker (1994) The Russian Conquest of Central Asia and Kazakhstan: Motives, Methods, Consequences,» in Hafeez Malik, ed., Central Asia: Its Strategic Importance and Future Prospects, New York: St. Martin"es Press, 1994, pp. 21-38.

Tarasov M.G. (2013) The Semirechye Cossacks in the Imperial Space of Russia . Journal of Siberian Federal University, Humanities \& Social Sciences, 2013, 1 issue 6: 74-84. 